P ISSN : 2503 - 1708

E ISSN : 2722 - 7340

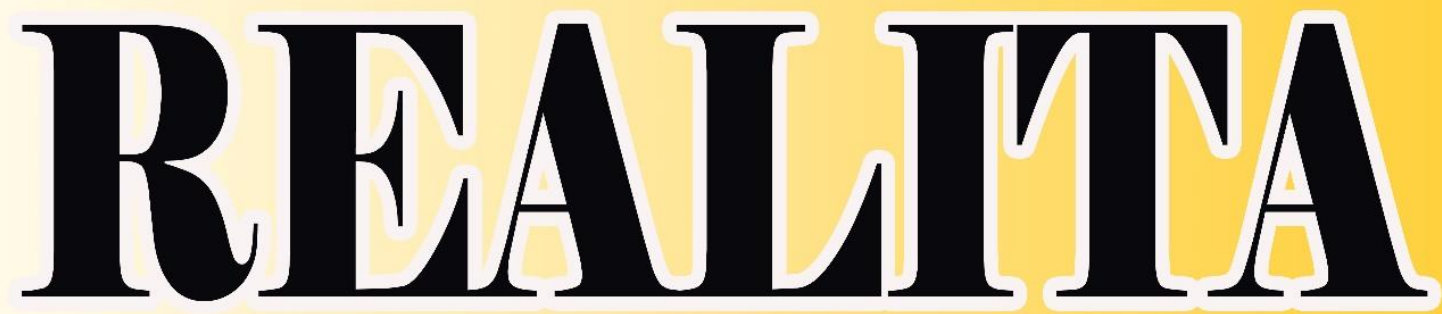

Jurnal Bimbingan dan Konseling

\begin{tabular}{|c|c|c|c|c|c|}
\hline JURNAL & VOLUME & NOMOR & EDISI & HALAMAN & P ISSN : 2503 - 1708 \\
REALITA & 6 & 2 & Oktober 2021 & $1326-1430$ & E ISSN : 2722 - 7340 \\
\hline
\end{tabular}

Diterbitkan oleh:

PROGRAM STUDI BIMBINGAN DAN KONSELING FAKULTAS ILMU PENDIDIKAN DAN PSIKOLOGI UNIVERSITAS PENDIDIKAN MANDALIKA 


\section{REALITA \\ BIMBINGAN DAN KONSELING \\ Jurnal Penelitian dan Pengembangan Pendidikan}

\section{DEWAN REDAKASI \\ Pelindung : Rektor Universitas Pendidikan Mandalika \\ : Dekan FIPP Universitas Pendidikan Mandalika \\ Penanggung \\ Jawab \\ : Kaprodi BK FIPP Universitas Pendidikan Mandalika \\ Editor}

Hariadi Ahmad, M.Pd

Universitas Pendidikan Mandalika

Associate Editor

Mustakim, M.Pd

Universitas Pendidikan Mandalika

Mujiburrahman, M.Pd

Universitas Pendidikan Mandalika

Ahmad Muzanni, M.Pd

Universitas Pendidikan Mandalika

M. Chaerul Anam, M.Pd

Universitas Pendidikan Mandalika

\section{Editorial Board}

Prof. Drs. Kusno, DEA., Ph.D

Universitas Negeri Jember Jawa Timur

Drs. Wayan Tamba, M.Pd

Farida Herna Astuti, M.Pd

Ichwanul Mustakim, M.Pd

Reza Zulaifi, M.Pd

Jessica Festi Maharani, M.Pd

Universitas Pendidikan Mandalika

Universitas Pendidikan Mandalika

Universitas Pendidikan Mandalika

Universitas Pendidikan Mandalika

Universitas Pendidikan Mandalika

\section{Reviwer}

Dr. I Made Sonny Gunawan, S.Pd., M.Pd

Universitas Pendidikan Mandalika

Dr. A. Hari Witono, M.Pd

Universitas Mataram NTB

Prof. Dr. Wayan Maba

Universitas Mahasaraswati Bali

Dr. Gunawan, M.Pd

Universitas Mataram NTB

Dr. Haromain, S.Pd., M.Pd.

Universitas Pendidikan Mandalika

Dr. Hadi Gunawan Sakti, M.Pd

Wiryo Nuryono, M.Pd

Hasrul, S.PdI., M.Pd

Dita Kurnia Sari, M.Pd

Dr. Roro Umy Badriyah. M.Pd., Kons

Universitas Pendidikan Mandalika

Universitas Negeri Surabaya Jawa Timur

STKIP Kie Raha Ternate Maluku Utara

UIN Sunan Ampel Surabaya Jawa Timur

Universitas PGRI Maha Dewa Bali

Ari Khusumadewi, M.Pd

Universitas Negeri Surabaya Jawa Timur 
M. Najamuddin, M.Pd

M. Samsul Hadi, M.Pd

Lalu Jaswandi, M.Pd

Eneng Garnika, M.Pd

Aluh Hartati, M.Pd

Drs. I Made Gunawan, M.Pd

Nuraeni, S.Pd., M.Si

Baiq Sarlita Kartiani, M.Pd

M. Zainuddin, M.Pd

Ahmad Zainul Irfan, M.Pd

Dra. Ni Ketut Alit Suarti, M.Pd

Asep Sahrudin, S.Pd., M.Pd

Suciati Rahayu Widyastuti, S.Pd., M.Pd

Rahmawati M, S.Pd., M.Pd

Ginanjar Nugraheningsih, S.Pd. Jas., M.Or

Dewi Ariani, S.Pd., M.Pd

St. Muriati, S.Pd., M.Pd

Uli Agustina Gultom, S.Pd., M.Pd

Indra Zultiar, S.Pd., M.Pd.
Universitas Pendidikan Mandalika

Universitas Pendidikan Mandalika

Universitas Pendidikan Mandalika

Universitas Pendidikan Mandalika

Universitas Pendidikan Mandalika

Universitas Pendidikan Mandalika

Universitas Pendidikan Mandalika

Universitas Pendidikan Mandalika

Universitas Pendidikan Mandalika

Universitas Pendidikan Mandalika

Universitas Pendidikan Mandalika

Univ. Mathla'ul Anwar Banten

Univ. Nahdlatul Ulama Cirebon

Universitas Muhammadiyah Kendari Sulawesi Tenggara

Universitas Mercu Buana Yogyakarta

Universitas Mahaputra Muhammad Yamin Solok Sumatera Barat

Universitas Bosowa Makassar Sulawesi Selatan

Universitas Borneo Tarakan Kalimantan Utara

Universitas Muhammadiyah Sukabumi Jawa Barat

\section{Alamat Redaksi:}

Redaksi Jurnal Realita Bimbingan dan Konseling (JRbk)

Program Studi Bimbingan dan Konseling

Fakultas Ilmu Pendidikan dan Psikologi Universitas Pendidikan Mandalika

Gedung Dwitiya, Lt. 3 Jalan Pemuda No. 59 A Mataram Telp. (0370) 638991

Email : realita@undikma.ac.id

Web : e-journal.undikma.ac.id

Jurnal Realita Bimbingan dan Konseling menerima naskah tulisan penulis yang original (belum pernah diterbitkan sebelumnya) dalam bentuk soft file, office word document (Email) atau Submission lansung di akun yang diterbitkan setiap bulan April dan Oktober setiap tahun.

Diterbitkan Oleh: Program Studi Bimbingan dan Konseling Fakultas Ilmu Pendidikan dan Psikologi Universitas Pendidikan Mandalika. 


\section{DAFTAR ISI}

Halaman

\section{Nuraeni dan Mastari}

Pengaruh Konseling Kelompok Terhadap Self Esteem Siswa Kelas XI di SMK Negeri 2 Kuripan

\section{Aprilia Yolanda, Ni Ketut Alit Suarti dan Ahmad Muzanni}

Pengaruh Body Shaming Terhadap Kepercayaan Diri Siswa SMA Negeri

1 Batulayar

$1342-1353$

\section{Hariadi Ahmad}

Hubungan Kestabilan Emosi dengan Kontrol Diri Siswa Sekolah Menegah Pertama

\section{Aluh Hartati}

Pengaruh Teknik Modeling Untuk Meningkatkan Empati Siswa

\section{Mustakim}

Pengaruh Teknik Cerita Terhadap Sikap Kemandirian Anak Pada Usia 5-6 Tahun

\section{Farida Herna Astuti dan Ichwanul Mustakim}

Keefektifan Bimbingan Kelompok dengan Teknik Role Playing untuk Meningkatkan Motivasi Belajar

\section{Mujiburrahman dan Soba Al-Qadri}

Hubungan Antara Kemampuan Kontrol Diri Dengan Penyusaian Diri Pada Siswa Kelas XI SMA Negeri 1 Taliwang

\section{Wiwiek Zainar Sri Utami}

Pengaruh Konseling Individu Terhadap Potensi Diri Anak Tunarungu di Sekolah Inklusi

\section{Baiq Nur'aini Cahya Khairani dan Ni Made Sulastri}

Pengaruh Layanan Konseling Humanistik Terhadap Perilaku Agresif pada Siswa Kelas XI IPS-4 di SMA Negeri 7 Mataram

\section{Najamudin}

Pengaruh Teknik Biblioterapi Terhadap Sikap Kemandirian Belajar Pada Siswa VIII SMP Negeri 5 Lembar

\section{Khaerul Huda}

Meningkatkan Pengetahuan dan Pemahaman Perilaku Hidup Bersih dan Sehat dimasa Covid 19 Melalui Metode Demontrasi pada Kelompok B di TK Negeri 01 Wanasaba 


\title{
MENINGKATKAN PENGETAHUAN DAN PEMAHAMAN PERILAKU HIDUP BERSIH DAN SEHAT DI MASA COVID 19 MELALUI METODE DEMONSTRASI PADA KELOMPOK B DI TK NEGERI 01 WANASABA
}

\author{
Oleh: \\ Khairul Huda
}

Dosen Program Studi Bimbingan dan Konseling Fakultas Ilmu Pendidikan dan Psikologi Universitas Pendidikan Mandalika Mataram Nusa Tenggara Barat Indonesia Email. khairulhuda@ikipmataram.ac.id

\begin{abstract}
Abstrak. Masalah dalam penelitian adalah bagaimanan meningkatkan pengetahuan dan pemahaman perilaku hidup bersih dan sehat melalui metode Demonstrasi, sedangkan tujuan penelitian adalah Meningkatkan pengetahuna dan pemahamana perilaku hidup bersih dan seshata melalui metode demonstrasi di kelompok b TK Negeri 01 Wanasaba kecamatan wanasaba kabupaen Lombok .Penelitian ini menggunakan penelitian tidakan kelas,subjek penelitian adalah kelompok B yang berusia 5-6 Tahun yang berjumlah 15 orang yang terdiri dari 6 orang laki-laki 9 orang perempuan.Teknik pengumpulan data yaitu observasi dan Dokumentasi.Teknik Analisis data yang digunakan analisis data deskriptif kualitatif dan deskriptif kuantitatif. Hasil penelitian Tindakan kelas yang dilakukan pada saat pra Tindakan perilaku hidup bersih dan sehat melalui metode demonstrasi, Pada kondisi awal sebelum tindakan sebesar $30 \%$ pada siklus I meningkat menjadi $60 \%$ dan pada siklus II menjadi 90\%. Penelitian dihentikan sampai siklus II karena sudah memenuhi criteria keberhasilan yang telah ditentukan yaitu minimal $80 \%$ dari keseluruhan anak perilaku hidup bersih dan sehatnya berada pada kriteria berkembang baik sesuai harapan.
\end{abstract}

\section{Kata kunci: Perilaku hidup bersih dan sehat, metode demonstrasi}

\section{PENDAHULUAN}

Perilaku Hidup Bersih dan Sehat atau biasa juga disebut sebagai PHBS adalah sekumpulan perilaku yang dipraktikkan atas dasar kesadaran sebagai hasil pembelajaran, yang menjadikan seseorang, keluarga, kelompok atau masyarakat mampu menolong dirinya sendiri di bidang kesehatan dan berperan aktif dalam mewujudkan kesehatan masyarakat (Kementerian Kesehatan RI, 2011). Hidup bersih dan sehat sendiri merupakan suatu hal yang seharusnya memang diterapkan dalam kehidupan sehari-hari oleh masyarakat sebagai salah satu cara menjaga kesehatannya.

Mengingat kesehatan merupakan hal penting bagi setiap manusia mulai dari konsentrasi dalam bekerja dan beraktivitas dalam kehidupan sehar-hari. PHBS adalah upaya memberikan pengalaman belajar bagi perorangan, keluarga, kelompok, dan masyarakat dengan membuka jalur komunikasi, memberikan informasi dan edukasi guna meningkatkan pengetahuan, sikap dan perilaku melalui pendekatan advokasi, bina suasana (social support), dan gerakan masyarakat (empowerment) sehingga dapat menerapkan cara-cara hidup sehat dalam rangka menjaga, memelihara, dan meningkatkan kesehatan masyarakat. Aplikasi paradigma hidup sehat dapat dilihat dalam program Perilaku Hidup Bersih Sehat (Depkes RI, 2006). Anak-anak TK 
Negeri 01 Wanasaba khususnya di kelompok B masih banyak yang belum mampu menerapkan PHBS seperti: belum mencuci tangan sebelum dan sesudah makan, membuang sampah pada tempatnya, buang air kecil tidak di WC, meludah disembarang tempat dan tidak menggunakan sabun cuci tangan.

Masyarakat sering menganggap pelaksanaan perilaku bersih dan sehat merupakan hal yang tidak begitu penting sehingga sering dalam pelaksanaannya tidak dilakukan secara benar. Peran orang tua sangat penting dalam mengajarkan perilaku hidup bersih dan sehat pada anaknya, bukan sampai tahap itu saja tapi juga sebagai pembimbing, memberikan pengertian, mengingatkan, dan menyediakan fasilitas kepada anak. Namun pengetahuan dan pemahaman yang kurang di masyarakat menyebabkan kurangnya juga pengetahuan dan pemahaman anak tentang perilaku hidup bersih dan sehat (Setiawan,2014).

Masuknya wabah Virus Corona di Indonesia membawa dampak besar terhadap kehidupan masyarakat, mulai dari kehidupan ekonomi, Kesehatan, social, keagamaan maupun di dunia Pendidikan. Dampak dari wabah ini dalam dunia Pendidikan bisa dilihat pada kebijakan pemerintah pusat hingga daerah yang mengeluarkan kebijakan untuk meliburkan seluruh Lembaga dari tingkat pendidikan anak usia dini (PAUD) sampai perguruan tinggi.hal ini dilakukan untuk upaya mencegah meluasnya penularan virus. Kondisi aktifitas Pendidikan yang diliburan ini, membuat proses pembelajaran yang dilakukan di rumah dan di ambil alih oleh orangtua. Orang tua dituntut untuk mampu mengganti peran guru di sekolah, sehingga membuat orang tua harus kreatif dalam mengajarkan anak-anak. Terlebih lagi bila anak masih dalam jenjang PAUD orang tua membutuhkan kreativitas sehingga anak bisa bermain sambal belajar di rumah.

Dalam kegiatan bermain sambil belajar merupakan kegiatan yang baik untuk anak. Menurut Hurlock (1993), bermain adalah setiap kegiatan yang dilakukan untuk kesenangan yang ditimbulkan tanpa pertimbangan hasil akhir. Melalui kegiatan bermain anak akan memiliki berbagai manfaat bagi perkembangan, aspek ini saling menunjang satu sama lain dan tidak dapat dipisahkan. Berdasarkan uraian di atas maka penulis tertarik untuk melakukan penelitian dengan judul Peningkatkan Pengetahuan Dan Pemahaman Perilaku Hidup Bersih Dan Sehat Melalui Metode Demonstrasi

\section{METODE PENELITIAN}

Adapun metode penelitian yang digunakan dalam penelitian ini adalah menggunakan penelitian Tindakan kelas ( PTK) yaitu penelitian yang dilakukan menggunakan pendekataan uji coba ( eksperimen ) terhadap metode pembelajaran tertentu untuk meningkatkan kualitas pembelajaran. Penelitian ini dilakukan karena adanya permasalahan dalam proses kegiatan kegiatan belajar mengajar di di kelas B TK Negeri 01 Wanasaba, sehingga peeliti menganggap perlu adanya suatu penelitian guna mengatasi permasaahan tersebut. Selain itu penelitian ini juga dilakukan supaya guru mampu memperbaiki metode yang digunakan sehingga anak-anakakan mencapai pengetahuna yang riil. Penelitian Tindakan kelas (PTK) adalah bentuk penelitian yang reflektif yang dilakukan oleh guru itu sendiri, yang hasilnya dapat dimamfaatkan sebagai alat untuk mengembangkan sekolah, pengembangaan keahlian, penerapan pembiasaan dan sebagainya (Sugiyono 2009). 
Penelitan tidakan kelas (PTK) ini menggunakan model kolaborasi yang megutamakan antara guru dengan peneliti untuk memperbaiki praktik praktik pembelajaran sehingga menjadi lebih efektif. Penelitian ini dimaksud kan untuk meningkatkan pengetahuan dan pemahaman perilaku hidup bersih dan sehat melalui metode Demonstrasi.

\section{HASIL PENELITIAN DAN PEMBAHASAN}

Dihasil dari hasil Tindakan yang telah dilakukan dari pra Tindakan sampai Tindakan siklus II Anak peningkatan pada perilaku hidup bersih dan sehat anak kelompok B TK Negeri 01 Wanasaba kecamatan wanasaba sangat baik melalui kegiatan pembiasaan. Untuk mengetahui perilaku hidup bersih dan sehat anak kelompok B TK Negeri 01 Wanasaba kecamatan wanasaba peneliti mengadakan Pra Tindakan dengan ketuntasan 4 orang atau $30 \%$, pada Siklus I menjadi 10 orang atau $60 \%$ dan pada Siklus II menjadi 14 atau 90\%. Dari hasil observasi perilaku hidup bersi dah sehat mulai dari pra tindajan sampai siklus II sebagai berikut:

Tabel Data hasil observasi perilaku hidup bersih dan sehat anak melalui metode demonstrasi serta pembiasaan mulai dari pra Tindakan sampai dengan siklus II.

\begin{tabular}{|l|c|c|c|}
\hline Aspek & $\begin{array}{c}\text { Pra siklus/ } \\
\text { Kondisi } \\
\text { awal }\end{array}$ & Siklus I & Siklus II \\
\cline { 2 - 4 } & $\begin{array}{c}\% \\
\text { Ketuntasan }\end{array}$ & $\begin{array}{c}\% \\
\text { Ketuntasan }\end{array}$ & $\begin{array}{c}\% \\
\text { Ketuntasan }\end{array}$ \\
\hline $\begin{array}{l}\text { Perilaku } \\
\text { hidup } \\
\text { bersih } \\
\text { dan } \\
\text { seshat }\end{array}$ & $30 \%$ & $60 \%$ & $90 \%$ \\
\hline
\end{tabular}

Sumber : Data olah di ambil pada 22 november 2021

Dari Tabel tersebut presentase ketuntasan perilaku hidup bersi dan sehat anak mengalami peningkatan yaitu pada kondisi prasiklus perilaku anak mencapai ketuntasan sebesar 30\%, pada siklus I meningkat menjadi $60 \%$, dan pada siklus II menjadi $90 \%$. Hasil penelitian tersebut telah memberikan gambaran bahwa perilaku anak mengalami perkembangana yang sangat cepat pada usia 5-6 Tahun pada kelompok B.

Perilaku hidup bersih dan sehat anak memang seharusnya sudah mencapai tahap atau indicator, anak mammpu memberikan hasil yang baik. dengan secara jelas bahwa hasil penelitian ini jika melihat hasil dari setiap siklus ,maka peningkatan perilaku hidup bersih dan sehat dapat di gambarkan seperti grafik dibawah ini:

Grafik peningkatan perilaku hidup bersih dana seahat anak melalui kegiatan pembiasaan perilaku dari prasiklus sampai dengan siklus II

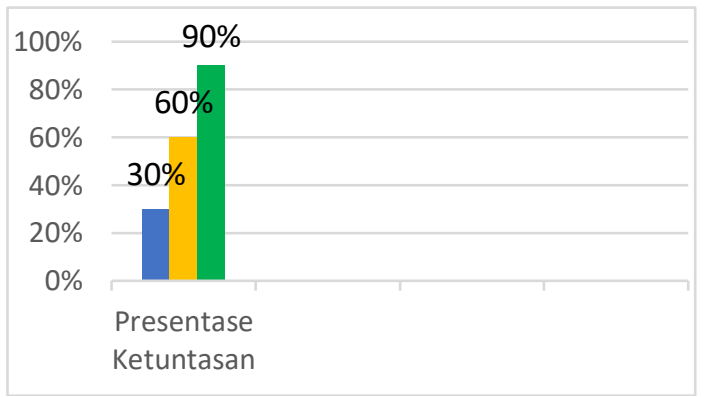

Dari grafik tersebut sangat jelas bahwa grafik anak yang berkembang sangat baikdari kondisi pra Tindakan meningkat terus sampai dengan siklus II, karna pada siklus II anak sudah mencapai kemampuan ketuntasan 90\% dan sudah melebihi target yang di harapkan yaitu $75 \%$,maka peneliti dapat memberikan pernyataan bahwa melalui metode demonstrasi dapat meningkatkan pengetahuan dan pemahaman perilaku hidup bersih dan sehat pada kelompok B TK Negeri 01 Wanasaba Mamben Daya Kecamatan Wanasaba Kabupaten Lombok Timur 
Berdasarkan pembahasan diatas, Perilaku hidup bersih dan sehat memiliki arti. menurut Depkes perilaku hidup bersih dan sehat (PHBS) ini merupakan sekumpulan perilaku yang dipratikkan oleh peserta didik, guru dan masyarakat sekolah atas dasar kesadaran sebagai hasil pembelajaran sehingga secara mandiri mampu mencegah penyakit, meningkatkan kesehatannya serta berperan aktif dalam mewujudkan lingkungan sehat. Metode demonstrai dapat meningkatkan pemahaman anak melalui penglihatan dan pendengaran. Anak diminta untuk memperhatikan dan mendengarkan baik-baik semua keterangan guru sehingga ia lebih paham tentang cara mengerjakan sesuatu. Dengan demikian selanjutnya anak dapat meniru bagaimana caranya melakukan hal tersebut seperti yang dicontohkan oleh guru. Menurut Menurut Moeslichatoen tujuan dan manfaat metode demontasi, yaitu: tujuan Metode Demonstrasi bagi Anak TK Sesuai dengan manfaat penggunaan metode demonstrasi bagi anak TK yang telah dikemukakan, demonstrasi merupakan salah satu wahana untuk memberikan pengalaman belajar agar anak dapat menguasai materi pelajaran dengan lebih baik. Melalui kegiatan demonstrasi anak dibimbing untuk menggunakan mata dan telinganya secara terpadu, sehingga hasil pengamatan kedua indera itu dapat menambah penguasaan materi pelajaran yang diberikan.

\section{SIMPULAN}

Berdasarkan hasil penelitian dan pembahasan dapat disimpulkan bahwa perilaku hidup bersih dan sehat anak pada kelompok B TK Negeri 01 Wanasaba Dapat ditingkatkan melalui metode demonstrasi. Di mana, Anak diminta untuk memperhatikan dan mendengarkan baik-baik semua keterangan guru sehingga ia lebih paham tentang cara mengerjakan sesuatu. Dengan demikian selanjutnya anak dapat meniru bagaimana caranya melakukan hal tersebut seperti yang dicontohkan oleh guru. Bukan hanya di contohkan guru juga selalu mengarahkan, membimbing dan membiasakan anak untuk berperilaku hidup bersih dan sehat (PHBS). Peningkatan Perilaku hidup bersih dan sehat melalui metode demonstrasi pada kelompok B TK Negeri 01 Wanasaba, dapat dilihat dari jumlah presentasenya dengan kriteria berkembang baik sesuai harapan. Pada kondisi awal sebelum tindakan sebesar $30 \%$ pada siklus I meningkat menjadi $60 \%$ dan pada siklus II menjadi $90 \%$. Penelitian dihentikan sampai siklus II karena sudah memenuhi criteria keberhasilan yang telah ditentukan yaitu minimal $90 \%$ dari keseluruhan anak perilaku hidup bersih dan sehatnya berada pada kriteria berkembang baik sesuai harapan.

\section{DAFTAR PUSTAKA}

Albar, Perilaku Hidup Bersih Dan Sehat

Untuk Petugas Puskesmas,

Medan: Dinas Kesehatan Propinsi

Sumatera Utara, 2003.

Aluh Hartati, Hariadi Ahmad dan Andika

Rifzar Mandasingi. 2020.

Hubungan antara Pengendalian

Diri dengan Prestasi Siswa

SMKN 1 Sumbawa Besar. Realita

Jurnal Bimbingan dan Konseling

Vol. 5 No 2 Edisi Oktober 2020.

Hal 1051 - 1066. Prodi

Bimbingan dan Konseling

Fakultas Ilmu Pendidikan dan

Psikologi Universitas Pendidikan Mandalika.

Arikunto, S., Suhardjono, dan Supardi,

"Penelitian Tindakan Kelas".

Jakarta: BumiAksara.2011 hal-16

Armai Arif, Pengantar ilmu Metodologi

Pendidikan Islam, (Jakarta:

Ciputat Pers,2002), hlm.40 
Departemen Kesehatan, Republik Indonesia, Perilaku Hidup Bersih dan Sehat (2006,2007,2008.2012)

Hariadi Ahmad dan Aluh Hartati. 2016. Panduan Pelatihan Self Advocacy Siswa SMP untuk Konselor Sekolah. LPP Mandala. Mataram

Hariadi Ahmad dan Aluh Hartati. 2016. Penerapan Teknik Structure Learning Approach dalam Meningkatkan Self Advocacy Mahasiswa Prodi BK IKIP Mataram. Realita Jurnal Bimbingan dan Konseling Vol. 1 No 2 Edisi Oktober 2016. Hal 117 - 127. Prodi Bimbingan dan Konseling Fakultas Ilmu Pendidikan IKIP Mataram

Hariadi Ahmad dan Dini Kurnia. 2017. Pengaruh Teknik Biblio Edukasi Terhadap Rasa Rendah Diri Pada Siswa Kelas XI di SMA Negeri 8 Mataram. Realita Jurnal Bimbingan dan Konseling Vol. 2 No 1 Edisi April 2017. Hal 194 202. Prodi Bimbingan dan Konseling Fakultas Ilmu Pendidikan IKIP Mataram

Hariadi Ahmad, Ahmad Zainul Irfan dan Dedi Ahlufahmi. 2020. Hubungan antara Pola Asuh Orang Tua dengan Penyesuaian Diri Siswa. Realita Jurnal Bimbingan dan Konseling Vol. 5 No 1 Edisi April 2020. Hal 950 - 966. Prodi Bimbingan dan Konseling Fakultas Ilmu Pendidikan dan Psikologi Universitas Pendidikan Mandalika.

Hariadi Ahmad, Aluh Hartati dan Jessica Festy Maharani. 2020. Pengaruh Dukungan Psikologis Awal pada Remaja dalam Pencegahan Covid 19. Realita Jurnal Bimbingan dan Konseling Vol. 5 No 2 Edisi Oktober 2020. Hal 1091 - 1106. Prodi Bimbingan dan Konseling Fakultas Ilmu Pendidikan dan
Psikologi Universitas Pendidikan Mandalika.

Hariadi Ahmad, Aluh Hartati, dan Nuraeni. 2018. Penerapan Teknik Structure Learning Approach (SLA) dalam Meningkatkan Kesadaran Empati Diri Siswa Madrasah Aliyah Al Badriyah. Realita Jurnal Bimbingan dan Konseling Vol. 3 No 2 Edisi Oktober 2018. Hal 600 - 605 Prodi Bimbingan dan Konseling Fakultas Ilmu Pendidikan IKIP Mataram.

Hariadi Ahmad, dan Lalu Andry Adifa Maulana. 2019. Pengaruh Teknik Video Edukasi Terhadap Berfikir Positif Siswa SMPN 16 Mataram. Realita Jurnal Bimbingan dan Konseling Vol. 4 No 1 Edisi April 2019. Hal 727 - 741. Prodi Bimbingan dan Konseling Fakultas Ilmu Pendidikan IKIP Mataram.

Hariadi Ahmad, dan Yolana Oktaviani. 2019. Pengaruh Teknik Self Instruction Terhadap Harga Diri Siswa Kelas Kelas XI di SMK Negeri 1 Lingsar Kabupaten Lombok Barat. Realita Jurnal Bimbingan dan Konseling Vol. 4 No 2 Edisi Oktober 2019. Hal 806 - 815. Prodi Bimbingan dan Konseling Fakultas Ilmu Pendidikan IKIP Mataram.

Hariadi Ahmad, Lidya Wurru dan Jessica Festy Maharani. 2021. Hubungan antara Keharmonisan Keluarga dengan Perilaku Agresif pada Siswa Madrasah Aliyah Raudlatusshibyan NW Belencong. Realita Jurnal Bimbingan dan Konseling Vol. 6 No 1 Edisi April 2021. Hal 1205 - 1212. Prodi Bimbingan dan Konseling Fakultas Ilmu Pendidikan dan Psikologi 
Universitas Pendidikan

Mandalika.

Hariadi Ahmad, Mustakim dan Syafaruddin. 2018. Hubungan antara Penyesuaian Diri dengan Berfikir Positif Siswa Kelas VIII SMP Negeri Seteluk Kabupaten Sumbawa Barat. Realita Jurnal Bimbingan dan Konseling Vol. 3 No 1 Edisi April 2018. Hal 482 494. Prodi Bimbingan dan Konseling Fakultas Ilmu Pendidikan IKIP Mataram

Hasrul dan Hariadi Ahmad. 2021. Mereduksi Prasangka Etnik Siswa dengan Teknik Restructuing Cognitive Suatu Krangka Konseptual. Realita Jurnal Bimbingan dan Konseling Vol. 6 No 1 Edisi April 2021. Hal 1213 - 1222. Prodi Bimbingan dan Konseling Fakultas Ilmu Pendidikan dan Psikologi Universitas Pendidikan Mandalika.

Kemendiknas, Peraturan Menteri Nasional Republik Indonesia Nomor58 Tahun 2009 Tentang Standar Anak Usia Dini, (Yogyakarta: Bina Insane Mulia 2010). 0

Moeslichatoen R, Metode Pengajaran di taman kanak -kanak,( Jakarta Rineka Cipta : 2004),lhm.123-124

Muri Yusuf. 2005. Dasar-dasar dan Teknik Evaluasi Pendidikan. Padang : UNP

Pedoman Penilaian Sikap, Pengetahuan dan Keterampilan Kurikulum 2013

Peraturan Menteri Pendidikan Nasional Republik Indonesia Nomor 58 Tahun 2009 Tentang Standar Pendidikan Anak Usia Dini. (2009).Jakarta: Departemen Pendidikan Nasional.
Permendikbud 146 Tahun 2014 tentang Kurikulum 2013 Pendidikan Anak Usia Dini.

Proverawati, Atikah.2012. Perilaku Hidup Bersih dan Sehat (PHBS). Yogyakarta: Nuha Medika

Setyosari, Punaji.2013. Metode penelitian kuantitatif kualitatif dan R\&D. Bandung: Alfabeta.

Sudjana, metode dan Teknik pembelajaran partisipasif, (Bandung: Falah Production. 2001). hlm.154-155

Sugiyono. (2004). Dasar-dasar Penelitian Bisnis.Bandung: Alfabeta.

Suharsimi Arikunto, et.al., Penelitian Tindakan Kelas, (Jakarta: Bumi Aksara, 2007), h.24

Zainal Aqil. (2006). Penelitian Tindakan kelas.Bandung:Yama Widya.

Zuhairini, dkk. Metode khusus pembelajaran Agama 


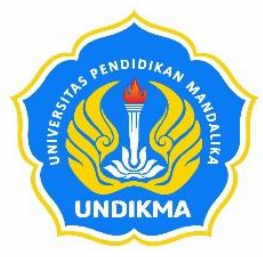

\section{UNIVERSITAS PENDIDIKAN MANDALIKA FAKULTAS ILMU PENDIDIKAN DAN PSIKOLOGI PROGRAM STUDI BIMBINGAN DAN KONSELING Jurnal Realita}

Gedung Dwitiya Lt.3. Jln Pemuda 59A Mataram-NTB 83125 Tlp (0370) 638991 e-mail: realita@undikma.ac.id; web: e-journal.undikma.ac.id

\section{PEDOMAN PENULISAN}

1. Naskah merupakan hasil penelitian, pengembangan atau kajian kepustakaan di bidang pendidikan, pengajaran, pembelajaran, bimbingan dan konseling, dan Psikologi

2. Naskah merupakan tulisan asli penulis dan belum pernah dipublikasikan sebelumnya dalam jurnal ilmiah lain,

3. Naskah dapat ditulis dalam Bahasa Indonesia atau Bahasa Inggris.

4. Penulisan naskah mengikuti ketentuan sebagai berikut:

$\begin{array}{llll}\text { Program } & \text { MS Word } & \text { Margin kiri } & 3.17 \mathrm{~cm} \\ \text { Font } & \text { Times New Roman } & \text { Margin kanan } & 3.17 \mathrm{~cm} \\ \text { Size } & 12 & \text { Margin atas } & 2.54 \mathrm{~cm} \\ \text { Spasi } & 1.0 & \text { Margin bawah } & 2.54 \mathrm{~cm} \\ \text { Ukuran kertas } & \text { A4 } & \text { Maksimum 20 halaman }\end{array}$

5. Naskah ditulis dengan sistematika sebagai berikut: Judul (huruf biasa dan dicetak tebal), nama-nama penulis (tanpa gelar akademis), instansi penulis (program studi, jurusan, universitas), email dan nomor telpon penulis, abstrak, kata kunci, pendahuluan (tanpa sub-judul), metode penelitian (tanpa sub-judul), hasil dan pembahasan, simpulan dan saran (tanpa sub-judul), dan daftar pustaka.

Judul secara ringkas dan jelas menggambarkan isi tulisan dan ditulis dalam huruf kapital. Keterangan tulisan berupa hasil penelitian dari sumber dana tertentu dapat dibuat dalam bentuk catatan kaki. Fotocopy halaman pengesahan laporan penelitian tersebut harus dilampirkan pada draf artikel.

Nama-nama penulis ditulis lengkap tanpa gelar akademis.

Alamat instansi penulis ditulis lengkap berupa nama sekolah atau program studi, nama jurusan dan nama perguruan tinggi. Penulis yang tidak berafiliasi pada sekolah atau perguruan tinggi dapat menyertakan alamat surat elektronik dan nomor telpon.

Abstrak ditulis dalam 2 (dua) bahasa: Bahasa Inggris dan Bahasa Indonesia. Naskah berbahasa Inggris didahului abstrak berbahasa Indonesia. Naskah berbahasa Indonesia didahului abstrak berbahasa Inggris. Panjang abstrak tidak lebih dari 200 kata. Jika diperlukan, tim redaksi dapat menyediakan bantuan penerjemahan abstrak kedalam bahasa Inggris.

Kata kunci (key words) dalam bahasa yang sesuai dengan bahasa yang dipergunakan dalam naskah tulisan dan berisi 3-5 kata yang benar-benar dipergunakan dalam naskah tulisan.

Daftar Pustaka ditulis dengan berpedoman pada Pedoman Penulisan Karya Ilmiah Universitas Pendidikan Mandalika. 


\begin{tabular}{|c|c|c|c|c|c|}
\hline & & & & \\
JURNAL & VOLUME & NOMOR & EDISI & HALAMAN & P ISSN : 2503 - 1708 \\
REALITA & 6 & 2 & Oktober 2021 & $1326-1430$ & E ISSN : 2722 - 7340 \\
& & & & \\
\hline
\end{tabular}

Alamat Qedaksi:

Program Studi Bimbingan dan Konseling Fakultas Ilmu Pendidikan dan Psikologi

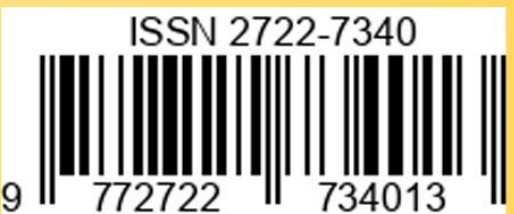

Universitas Pendidikan Mandalika

Gedung Dwitiya, Lt. 3 Jalan Pemuda No. 59A Mataram Telp. (0370) 638991

Email : realita@undikma.ac.id

Web : e-journal.undikma.ac.id

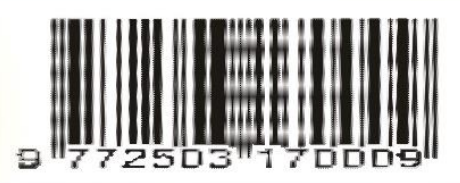

